\title{
"A Small Town with a Pretty Big Idea": How Ames, Iowa, Came to Have the Most Enduring Resource Recovery Plant in the United States
}

\author{
ANGIE GUMM
}

ON JULY 13, 1979, more than a week after President Jimmy Carter had mysteriously disappeared to Camp David, trying to discover the root of America's problems - energy and other the Des Moines Register's Donald Kaul wrote,

Two months ago, you hardly ever heard of synthetic fuel; now you hear of little else. Congressmen are knocking each other down to get in the forefront of those in support of 'synfuels' as they are called. President Carter is said to be on his way down from the mountaintop with a crash program to develop a synthetic-fuels industry. It seems to be an idea whose time has come - which is a fair indication of what rotten times we live in. Synthetic fuels is a rotten idea. It's the modern version of the medieval search for the Philosopher's Stone, a mythical method of turning lead into gold, and about as practical. ${ }^{1}$

\section{Des Moines Register, 7/13/1979.}

I thank the State Historical Society of Iowa for the research grant that made this project possible; Lorrie Hanson, John Pohlman, Rob Weidner, and the Arnold O. Chantland Resource Recovery Plant; Alan Spohnheimer and the Ames Historical Society; the clerks at the City of Ames; Iowa State University Special Collections; the participants in the 2008 WHEATS Workshop at Kansas State University; Marvin Bergman and the anonymous reviewers of the Annals of Iowa; and especially Pamela Riney-Kehrberg, Charles Dobbs, John Monroe, Amy Bix, and Julie Courtwright, my wonderful dissertation committee.

THE ANNALS OF IOWA 71 (Fall 2011). (C) The State Historical Society of Iowa, 2011. 
In what came to be known as his "Malaise Speech," Carter did not talk about synthetic fuels. Instead he focused on the crisis of confidence America was experiencing at the end of the decade. The country that had put a man on the moon exactly ten years earlier had grown doubtful of its future thanks to a decade filled with political corruption, shortages, excessive consumerism, and an onslaught of technological failures, especially in the previous year. ${ }^{2}$ Even though he did not mention it, the president did plan a massive funding of synfuel research and development along with numerous associated technologies, including over $\$ 2$ billion for waste-to-energy efforts. ${ }^{3}$

Kaul's objections to the high-tech fuels, which turned oil shale, coal, tar sands, and possibly garbage into oil and gas, were shared by environmental groups like the Sierra Club, which called the president's plan a "disaster." ${ }^{4}$ To opponents, synfuels had the potential to cause environmental harm; used too many other precious resources such as water and land; were too expensive and risky; and did nothing to encourage voluntary conservation, which was the easiest and cheapest way to save energy. The meaning of Carter's support despite all of these problems offended environmentalists the most: that energy production trumped all other concerns about resources and the environment.

That was not the case for most Americans during the 1970s, however. A study of the issue of solid waste management reveals that most environmental attitudes during that decade were not polemical ideologies entrenched at far ends of a spectrum. Instead, during the 1970s a wide range of people and groups accepted the general supremacy of technology and the market but believed that they could be guided by a conservationist ethic that acted in humanity's best long-term interests.

2. During the year before the speech, Love Canal was declared a national disaster, Three-Mile Island had its meltdown, Flight 191 crashed, and Skylab was about to fall from the sky.

3. "Federal Programs Impacting Urban Waste Problems," Carter Presidential Staff Offices, Cabinet Secretary Office Ed Helminski, box 190, Urban Waste Management/Resource Recovery, Jimmy Carter Presidential Library and Museum, Atlanta, Georgia.

4. "A Time to Choose: Synthetic Fuels and the American Future," Sierra Club National News Report, 7/27/1979. 
Resource recovery was the embodiment of this cooperative, technology-centered environmentalism. Resource recovery plants came in a variety of types, but all of them extracted resources that could be recycled and sold in the market and converted the rest of the waste into some form of energy. By the time Carter unveiled his plan, failed and abandoned resource recovery plants were sprinkled across many major cities of the United States, and the Environmental Protection Agency had decided to drop future efforts from its plate. Resource recovery was too high tech and expensive, officials had decided. European mass-burn facilities, which had fewer parts and produced only energy, were simpler, cheaper, and more reliable.

The goal of turning waste into energy, however, did not win over the environmentalists who had accepted the compromises of the more conservation-minded resource recovery. Carter's plan was not fully implemented, and many cities abandoned their waste-to-energy (WTE) plants when they lost federal support in the 1980s. In fact, American solid waste management has progressed little since the 1970s; by 1995 every state either exported or imported (or both) waste, and by 2000, 32 million tons of trash were being transported from one state to another. ${ }^{5}$

Only one of the highly technical resource recovery systems would survive from the 1970s to the present day. Ames, Iowa, alone has persisted in its resource recovery efforts even in the face of high prices and international controversy, all the while clinging to old conservationist values that have lost and regained popularity through the decades. Iowans' esteem of farmland combined with the city's acceptance of engineering efforts and goals created a unique situation that has enabled the resource recovery plant to carry on for all of these years. Its story offers a rare case study that shows us the unforeseen issues that can emerge when a city not only pursues an alternative energy but commits to it.

In 1973 The American City magazine ran a story titled "SolidWaste Disposal - Five Years to Doomsday." It compared the garbage situation to the "nuclear clock of the atomic scientists which warned civilization that only five minutes remained be-

5. Martin Melosi, Garbage in the Cities: Refuse, Reform and the Environment (Pittsburgh, 2005), 215. 


\section{A small town with a pretty big idea.}

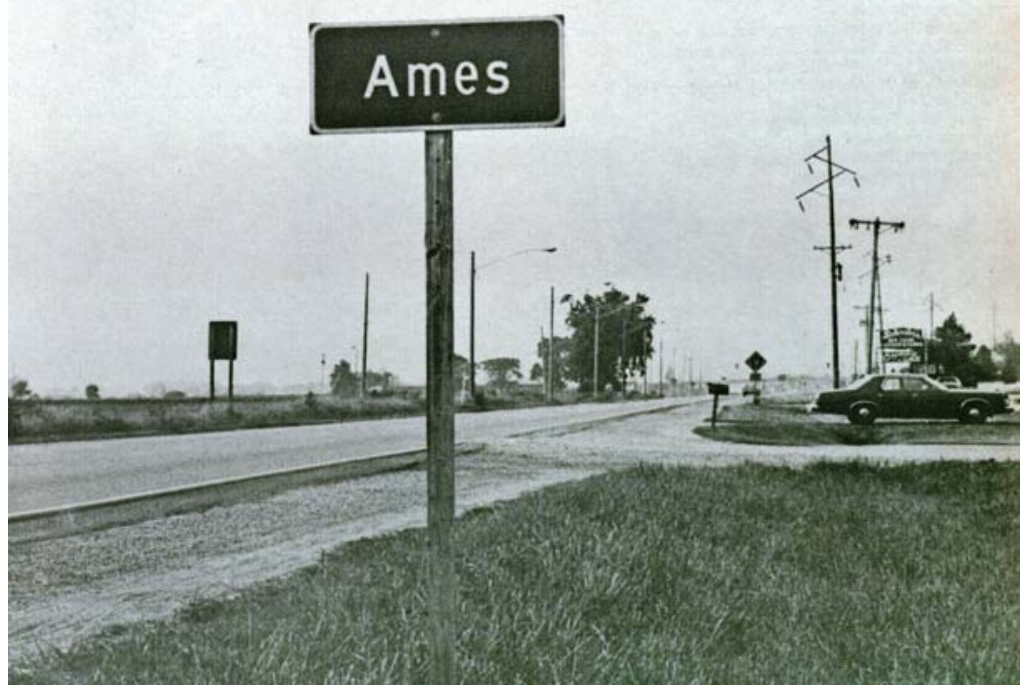

When U.S. Representative Tom Harkin testified at a congressional hearing about resource recovery, he agreed with the claim of an advertisement taken out by a manufacturer of some of the components of Ames's resource recovery plant: Ames was indeed "a small town with a pretty big idea." From Saturday Evening Review, 12/13/1975, p. 43

fore extinction." Should cities simply do nothing because local governments cannot reach any consensus, the article asked. "The little Iowa city of Ames doesn't think so," the author wrote. "Ames is unafraid. It has agreed to receive refuse from nine other nearby municipalities. It will use this refuse as a fuel to generate electricity in its municipally owned power system, sulfur free, incidentally." ${ }^{\prime 6}$ By the time the plant opened, Ames was touting itself as a "small town with a pretty big idea."

6. William S. Foster, "Solid-Waste Disposal - Five Years to Doomsday," The American City, July 1973, 8.

7. Tom Harkin, Hearing before the Subcommittee on the Environment and the Atmosphere of the Committee on Science and Technology, U.S. House of Representatives, 94th Cong, 2nd sess., 4/7/1976, 4/8/1976, 4/12/1976, 4/13/1976, 48. 
THE IDEA for the plant germinated at a city council meeting in October 1971 when councilman Ray Fisher suggested that Ames look into an "experiment in waste disposal" he had recently seen that might save the city some money. ${ }^{8}$ Regulations against feeding garbage to pigs and the open burning of dumps caused municipal solid waste across the country to accumulate at greater rates in the 1960s than ever before, as did the nation's affluence. By 1970, the Ames landfill contained 6,000 junked cars, the byproduct of a society so rich that it was more likely to throw away than to fix up something even as expensive as a car. Even after the city removed the vehicles, the landfill was expected to be full by 1975, so Mayor Stuart Smith assembled a solid waste task force to start looking for new sites very early in the decade. ${ }^{9}$

A new landfill would have to meet the standards established by the recently founded federal Environmental Protection Agency (EPA). The city estimated that the cost to dispose of trash would increase from $\$ 1.50$ to $\$ 2.50$ per ton in a regulated landfill. Ames was not the only city running out of landfill space. Neighboring communities were also out of room and not yet prepared to site or fund new landfills. Before hiring the consulting firm of Gibbs, Hill, Durham and Richardson in October 1972, Ames had implemented a "stop gap" solution earlier that year, agreeing to take all of Story County's garbage for $\$ 3$ per ton. It was not surprising that area leaders readily agreed to the expensive, temporary solution. By the middle of the decade, the new regulations and increasing environmental awareness would cause most of the country's mayors to declare that solid waste disposal was their "number one headache." ${ }^{10}$

The Ames Daily Tribune's editorial board endorsed Fisher's "experiment," noting that a new landfill could cause water pollution and would take "enormous amounts of space." ${ }^{11}$ The ex-

8. Minutes, Ames City Council, 10/19/1971, Ames City Hall, Ames.

9. Ames Daily Tribune, 11/11/1970; "Ames Pioneers with New Solid Waste System," Key to the City (City of Ames newsletter), August 1973, 6, Ames Historical Society, Ames; Iowa State Daily, 5/18/1973.

10. Iowa State Daily, 5/18/1973; Minutes, Ames City Council, 10/10/1972; Ames Daily Tribune, 11/18/1971; Tom Redburn, "The Tug-of-War over Waste," Environmental Action 22 (May 1976), 3-4.

11. Ames Daily Tribune, 10/22/1971. 
periment was a resource recovery plant - the great hope for solid waste disposal in the late 1960s and 1970s. The EPA spent millions of dollars funding demonstration grants for a handful of cities to build resource recovery plants that other cities could study. Although many local governments were interested in resource recovery, it was mostly large cities that actually pursued the plants. Even with government aid, the costs were so high and the technology so uncertain that municipal solid waste resource recovery projects were usually only worthwhile for cities that had a lot of people and little available land.

In Ames, a small city with a rapidly growing population (but still under 50,000) and plenty of available land, planners projected that the disposal fee would be $\$ 2.69$ per ton with the plant, with hopes that it would drop to a mere 60 cents per ton in about a decade. Area leaders devised a plan for all participating communities to pay the same price, so other Story County communities were getting a small bargain compared to their previous agreement. ${ }^{12}$ While Ames had some immediate and local reasons to consider resource recovery, a new environmental ethic along with the national energy and farmland crises that occurred before construction began in October 1973 would become more important than price issues and provide the city with lasting justifications for the plant.

Just as the growing piles of garbage caused Americans to worry about pollution and waste in the 1960s, works like Rachel Carson's Silent Spring, Garrett Hardin's "Tragedy of the Commons," and Paul Ehrlich's The Population Bomb, also alerted Americans to the threats posed by chemicals and scarcity. ${ }^{13}$ The extent of the country's environmental concern became apparent after the wildly popular first Earth Day on April 22, 1970. Iowans were also considering their role in environmental issues during this period. When the U.S. Foreign Policy Association issued a pamphlet titled "Man and His Environment - What Price Survival?" the Ames Daily Tribune reported that "scores of Iowa programs dealing with this universal challenge are gaining mo-

12. Iowa State Daily, 5/18/1973.

13. Rachel Carson, Silent Spring (Boston, 1962); Garrett Hardin, "The Tragedy of the Commons," Science 162 (1968), 1243-48; Paul R. Erlich, The Population Bomb (New York, 1971). 
mentum. The press, radio and television are giving it major play. Pastors are emphasizing the Ecological Crisis. Youth are finding handles to take hold of in tackling the proposition. Leaders in industry are recognizing that 'the first responsibility of business is to operate for the well-being of society.'

Ames was certainly no exception to this evolving environmental consciousness. The local paper was full of articles about environmental issues and even featured a series on world hunger. In October 1971 alone, two speakers came to Ames to discuss population and the earth's carrying capacity. One of the speakers, agricultural expert and former Iowa State University (ISU) student and professor William C. Paddock, visited his alma mater to warn about the pending food crisis. Paddock said that a food crisis in 20 or 30 years was "unavoidable." ${ }^{15}$

Paddock's worry was also a political concern in the early 1970s. When famine hit desperate countries around the globe, seeming to offer proof of the pending environmental calamity, U.S. Secretary of Agriculture Earl Butz encouraged farmers to grow as much as possible, reversing a decades-long policy of discouraging agricultural overproduction, dating back to the Great Depression. The United States could profit from the exports economically and, by providing aid to the Soviet Union in the cold war climate, could display technological one-upmanship. On the other hand, as historian Tim Lehman has noted, concerns about soil erosion and fuel shortages became prevalent just as farmers were being called upon to feed the world. "This volatile mixture of political, economic, demographic, and environmental change," he writes, formed the backdrop for a serious "attempt to plan for the use of American farmland." ${ }^{16}$ In light of the growing needs and tightening constraints, it seemed foolish and wrong to turn good farmland over to garbage.

Another of the decade's serious problems, the energy crisis, began in 1973, just as construction of the Ames resource recovery plant started. A substantial portion of the city's energy came

14. Ames Daily Tribune, 10/8/1971.

15. Ames Daily Tribune, 10/12/1971, 10/29/1971.

16. Tim Lehman, Public Values, Private Lands: Farmland Preservation Policy, 19331985 (Chapel Hill, NC, 1995), 44. 
from coal, while the crisis was linked to the 1973-1974 oil embargo. But as other cities and states also started switching to coal, the fact that Iowa imported about 98 percent of its energy from other states became more of an issue, especially when the price of coal jumped 50 percent from 1974 to $1976 .^{17}$ Promoters of the Ames resource recovery plant offered the energy crisis as further justification that the plant ought to be built. Researchers hoped that Ames would be an example to the rest of the state of the potential to use waste for fuel, and many believed that the state might become completely energy self-sufficient by turning agricultural waste into energy.

One of those true believers was state senator and poultry farmer Hilarius Heying. When Heying received notice that his Dyersville gas supply was in jeopardy in 1974, he teamed up with a Des Moines company called Sunny Time Energy to turn the manure from his farm's 160,000 chickens into a continuous supply of energy for his farm. The $\$ 75,000$ system, called POOP 4 , received a $\$ 50,000$ grant from the state energy department council. ISU professors offered to work with Heying to develop a five-year plan of study of the conversion of methane to energy. Like most alternative energy efforts of the 1970s, mechanical difficulties caused the plant to fail, and it lost its government funding. ${ }^{19}$ Heying unsuccessfully continued to push the state to invest in turning waste - of all sorts - into energy. He asked his colleagues in the state senate to picture that "every community could be self-sustaining if all the hidden energy in our wastes were frugally recycled. I have made a couple of years study of this - I have spent some fifty thousand dollars for worthless

17. Iowa State Daily, 12/13/1973; Public Power (official publication of the American Public Power Association), September-October 1974, 28; Changing Scene (newsletter of the Ames Laboratory), vol. 2, no. 89, p. 1, Special Collections, Iowa State University (ISU) Library, Ames.

18. Changing Scene, vol. 2, no. 89, p. 1.

19. Larry Murphy, "Methane Making Electricity at West Union," undated clipping from the Des Moines Register in Hilarius Heying Papers, MS 250, Special Collections, ISU Library, Ames; R. J. Smith, assistant professor, Iowa State University, to Senators T. Riley and H. L. Heying, 4/19/1974, ibid. An article by George Anthan, "The Ingenious Iowan: Beer Cans, Chicken Droppings Provide Energy," in the Des Moines Register, 5/12/1980, describes some of the solar, wind, and battery-powered energy-saving efforts of the decade. 
equipment, but I have learned a great deal. Now that we are running out of landfills and now that the sewage is creeping up from the ocean bed onto our eastern and western seashores, we must be motivated to action." ${ }^{20}$

Because most state and local governments could not, however, afford to finance experimental energy projects, the federal government began funding resource recovery demonstration programs. The goal was to let one city learn from and tinker with the technological mishaps that would inevitably arise with any plant scale-up, so that other communities could invest in technology that was no longer experimental. ${ }^{21}$ As all of the demonstration plants failed by the end of the 1970s and the federal government began the switch to European-style waste-to-energy plants, the lesson most cities took away was not to invest in resource recovery. The city of Ames had jumped on the bandwagon early, however, before some of the demonstration plants were even funded, let alone failed. The city surveyed several resource recovery systems and decided to model its on the first demonstration plant, the St. Louis-Union Electric plant, which began operating in 1972.

In the St. Louis system, a hammer shredded municipal solid waste (MSW) that was then fed into an air separator. The heavy material, which usually was non-combustible, dropped down to a magnetic belt and was separated into ferrous and nonferrous materials that would be recycled or sent to a landfill. The lighter material went into a "cyclone separator," where it was separated once more. The remaining MSW, the light material, was stored and then packed into semi trucks, which hauled the waste to a Union Electric power plant, where it could be fired with coal to provide energy for the city. The product was called refuse-derived fuel (RDF). This process was the most appealing to the city of Ames, which hoped to build its facility near its municipally owned power plant and install a pneumatic tube to transfer the waste. The full-sized St. Louis plant was never built because Union Electric backed out after difficulties

20. Senator Hilarius Heying, speech for state senate about Senate File \#1126, Hilarius Heying Papers.

21. Angie Gumm, "Looking for the Good in Garbage: Bill Compton Builds Wichita a Pyrolysis Plant," Kansas History 31 (2008), 216. 
siting transfer stations and new laws regarding utility research and development made the plant unaffordable, according to the company. ${ }^{22}$ The Ames plant was unusual in that it was to be owned and operated by the city rather than a utility or technology company. Consequently, it would never be subject to the whims or economic needs of a private corporation that had to answer to stockholders.

Upon the recommendation of the consulting firm, the city proceeded with the RDF plant and put out calls for bids for the plant's numerous parts in 1973. The initial expected cost was $\$ 2.8$ million, which would be funded primarily through general obligation bonds that did not require a vote by citizens. The plant apparently had plenty of local support, however. Mayor Stuart Smith considered the plant one of his highest priorities, and City Manager J. R. Castner claimed, "In nearly 25 years in local government I've never been involved with a project that everyone in town thinks is the greatest thing that has come down the tube since the toothbrush. People stop me on the street and at cocktail parties to ask how the plant is coming along and when they can go through it." ${ }^{23}$ The Ames League of Women Voters undertook a major study, which supported the plant. ISU and the Story County communities that had been using the Ames landfill all agreed to 25-year contracts to use the Ames plant for all of their solid waste disposal needs. Both mayoral candidates and several of the city council candidates in 1973 also expressed pride in the plant. ${ }^{24}$ There is one clue that

22. H. Lanier Hickman Jr., The History of Solid Waste Management in the United States (Santa Barbara, CA, 2003), 223-24; L. J. Shannon et al., St. Louis Refuse Processing Plant: Equipment, Facility, and Environmental Evaluations (Washington, DC, 1975), 5, 8; Daniel M. Doran, Energy from a Wasted Resource: The Ames Experience (Ames, 1996), 4.

23. Ames Daily Tribune, 5/17/1973; J. R. Castner, "The Ames, Iowa Resource Recovery Story," Nation's Cities, August 1975, 30.

24. "League of Women Voters Endorses Heat Recovery and Recycling as Waste Disposal Methods," folder 9, box 14, League of Women Voters of Ames Records, MS 341, Special Collections, ISU Library; Laura Miller, "Contemplating Conservation, Aldo Leopold," Leopold Letter 21, no. 1 (Spring 1992), at www.leopold.iastate.edu/pubs/nwl/2009/2009-1-leoletter/leopold.html (accessed 3/28/2011); Terry V. Sprenkel, "Development of the Ames SystemIncentives to Solve a Problem," Proceedings of the Solid Waste to Energy Conference - The Ames Experience (Ames, 1978), 43; Iowa State Daily, 10/25/1973, 10/26/1973, 11/1/1973. 
some Ames residents had reservations, however. Council candidate Dennis Sweeney, who claimed to base "his opinions entirely on the views of the people in the third ward," told the Iowa Student Public Interest Research Group (ISPIRG), "The solid waste disposal program has some good possibilities, but not without further research and a Federal funding program. ${ }^{\prime 25}$ That is the only negative comment about the plant found in the local paper during the early years.

There may have been little local resistance, but there was also little national attention or federal support, even though, increasingly, as the St. Louis plans began to unravel, it seemed likely that Ames would have the first full-scale implementation of the RDF technology. Ames was building the first municipally operated waste-to-energy plant, yet it did not qualify for a demonstration grant because it was using technology from the St. Louis plant. While the EPA provided multi-million-dollar funding to the ten demonstration plants that would soon fail, the agency only gave Ames a $\$ 600,000$ grant to buy degritting, dust collection, and sprinkler systems. The EPA also provided a $\$ 750,000$ grant to the city, which distributed it to ISU to fund professors and students as well as the Ames Laboratory to study the "Ames Experience" for three years. The study included environmental, technical, economic, and political aspects of the plant. ${ }^{26}$

The city of El Cajon, California, was working on another type of resource recovery, a pyrolysis plant for which it had received demonstration plant money. The disposal technique was quite different, but the size of the plant and the community it would serve were both similar to the Ames plant. Both cities were taking risks to provide trash service for the same number of people, so it did not seem fair, at least to the Ames Daily Tribune editorial board, that El Cajon was getting so much government assistance and attention. "It may be that El Cajon has a

25. Ames Daily Tribune, 11/2/1973.

26. "Gibbs, Hill, Durham and Richardson Memorandum of Understanding dated May 10, 1977," Minutes, Ames City Council, 11/11/1977; Engineering News Record, 9/5/1974, 13; S. Keith Adams, "The Economics of Solid Waste Resource Recovery - Analysis of the Ames System," Proceedings of the Solid Waste to Energy Conference, 73. 


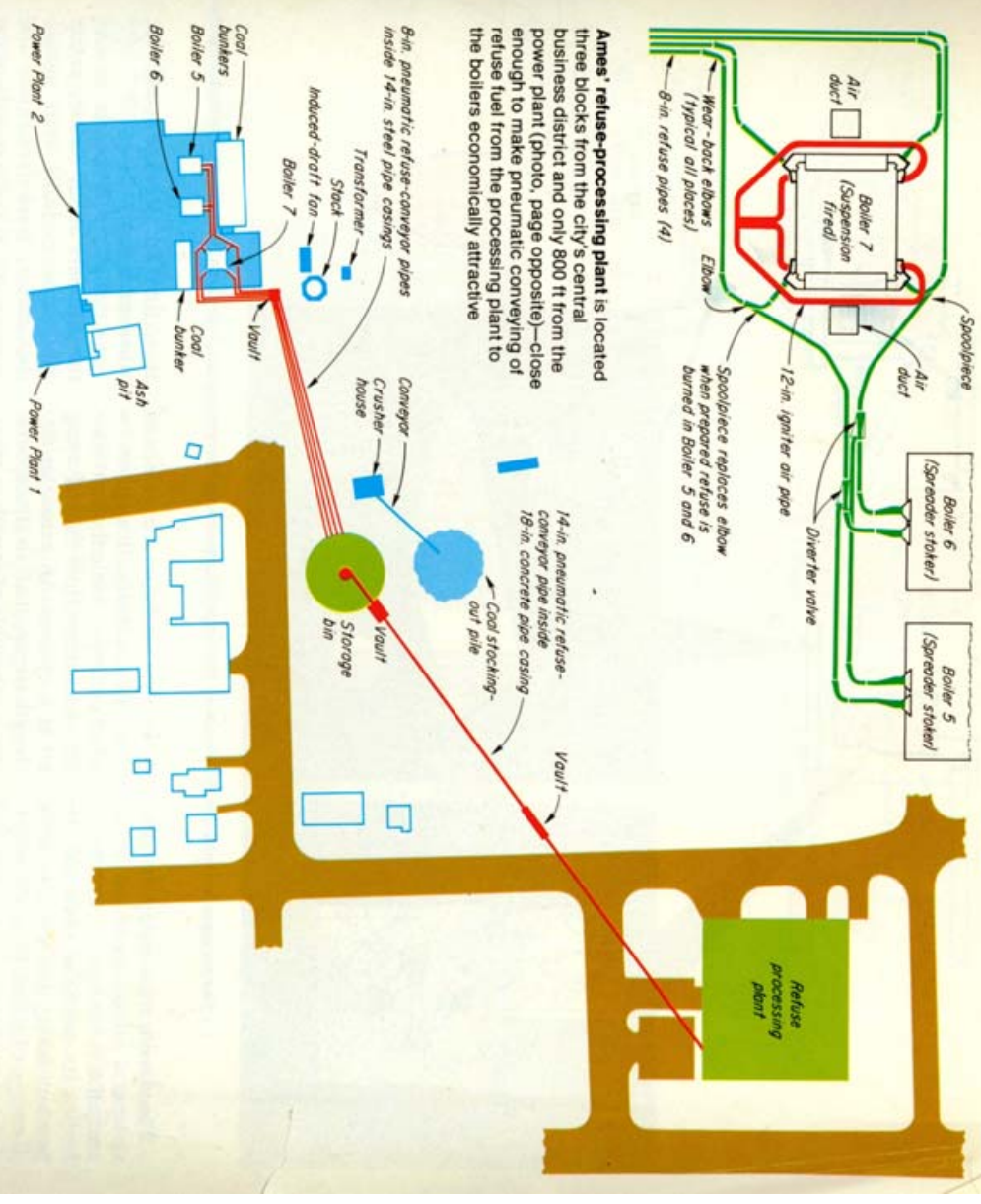

The Ames plant's relatively small size and its proximity to the power plant contributed to its success. From James J. O'Connor, The 1975 Electric Utility Generation Planbook (New York, 1975), 37.

better publicity system than Ames," the board wrote. "But so far little has been made of the efforts here. But it remains that on paper, the Ames operation is more impressive than the morepublicized California plan." ${ }^{27}$

27. John D. Parkhurst, Report on Status of Technology in the Recovery of Resources from Solid Wastes (Los Angeles, 1976), 123; Proceedings of the Solid Waste to Energy Conference, v; Ames Daily Tribune, 1/30/1974, 1/8/1974. 
JUST AS the Tribune had said, the Ames plant was impressive. Haulers entered a 30-foot-high room and dumped their trash on a tipping floor. A worker in a machine called a loader mixed the material, combining wet and dry trash at a ratio to encourage combustion of all the waste. The mixture was then put on a conveyor belt called a feeder and entered the primary shredder. At that stage the garbage was ripped to shreds by 48 130-pound hammers with a 1,000-horsepower motor. It then passed through the degritter, where small pieces of waste were captured by disc screens and the larger pieces continued on through the process. The degritted material, typically non-combustible, ended up in the landfill. The large items were put on an electromagnet conveyor, to remove 90 percent of the ferrous metals. The remaining waste then passed through a secondary shredder, where it was torn into two-inch pieces. At that point the material entered the air classification system, similar to St. Louis's cyclone. As the waste went into the air classifier, the heavy materials fell to the bottom, while the lighter waste floated up in the air and was sucked into a pneumatic tube and carried to the RDF storage bin over at the nearby power plant. Conveyors then sent the material into one of two coal boilers, where it was cofired with coal at a ratio of about 70-80 percent coal to 30-20 percent RDF. ${ }^{28}$

The plant could process up to 200 tons of waste per day. Its relatively small size was an asset. Larger utilities usually fired 100 percent coal during their peak hours, reducing the amount to $30-40$ percent at night. They bought the rest of their power from a pool, thus avoiding wasting fuel that was not needed. When cofiring coal with RDF, however, the off-time slackening could not occur because the flow of RDF to the boiler could not be reduced; the ratio of coal to waste had to be maintained evenly. An RDF system was, therefore, more expensive for larger utilities to adopt. Consequently, Ames became "the first and the big major contributor to [RDF] technology." In May 1976 Jerry Temple, the plant's superintendent, informed U.S. Representative Tom Harkin, "We feel we have a solution to a problem and hope more people will look into recovery and do it."

28. Doran, Energy from a Wasted Resource, 3-4, 13.

29. Al Joensen, ISU professor of mechanical engineering, who studied the plant under the grant funded by the EPA, interview with author, 7/28/2009, Ames; 
The Ames plant was not without its own problems, however. Inflation and unexpected costs caused the plant's start-up cost to soar. Its final total cost was $\$ 6.3$ million, nearly two-and-a-half times original estimates. Then, instead of dropping to 60 cents per ton or even producing a profit of over $\$ 2$, as the city had ambitiously predicted in the early years, the plant's disposal fee went through the roof. In 1977 the cost of disposal was \$11 per ton, while the rest of Iowa was paying between $\$ 4$ and $\$ 7$ per ton for landfills. The town of Gilbert paid $\$ 8,000$ per year to use the Ames facility, ten times the amount it would have cost to use the Boone County landfill 20 miles away. Story County communities that had signed 25-year contracts began to question their decision. When the power plant increased its rates, many people argued that the city should sell it to another utility provider and replace the costly resource recovery plant with a landfill. ${ }^{30}$

Nearly all resource recovery plants across the country tended to cost more than expected because of mechanical or marketing problems, or a combination of both. Another issue was that people were not producing as much trash as cities had predicted. Landfills last longer when less trash is produced, but more trash allows resource recovery plants to lower their costs. The Ames plant had enough trash to fulfill its role in the cofiring process, but resource recovery plants also made money from the separated resources that were sold to recycling companies. Ames expected to receive nearly 55,000 tons of trash in 1975. In its first three months of operation, the city shipped 542 tons of ferrous metals, bringing in over $\$ 44,000 ; 120$ tons of wood chips were sold for $\$ 15$ per ton; and a relatively shortlived motor oil container held up to 10,000 gallons of used oil, which was expected to sell for ten cents per gallon. When some Ames citizens complained that paper was just being wasted in

Harkin, Hearing before the Subcommittee on the Environment and the Atmosphere, 4/7/1976, 4/8/1976, 4/12/1976, 4/13/1976, 56.

30. Petros Gheresus, S. Keith Adams, John C. Even, and Robert A. Olexsey, "Resource Recovery from Solid Waste: The Ames System Experience with Economics and Operation," National Waste Processing Conference, 1980, at www.seas.columbia.edu/earth/wtert/sofos/nawtec/1980-National-WasteProcessing-Conference/1980-National-Waste-Processing-Conference-44.pdf (accessed 6/6/2011); Ames Daily Tribune, 4/8/1971; John Pohlman, interview with author, 5/6/2009, Ames. 


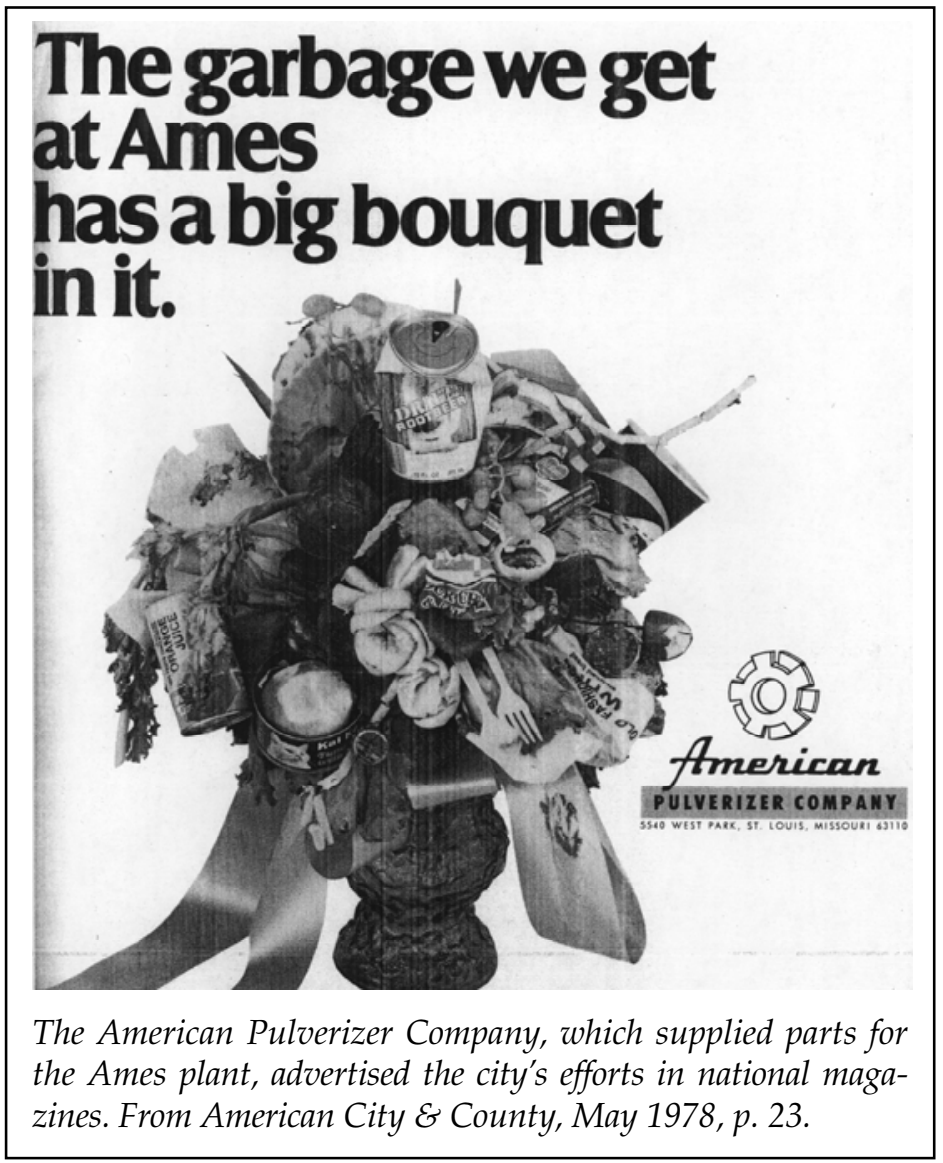

the recovery process, the city built a paper recycling annex next to the plant. The paper was sold for up to $\$ 40$ per ton or burned depending on the economic markets.

The city's willingness to seek markets for even seemingly worthless types of material demonstrated a true conservationist ethic. A plaque on the door of the plant, a reminder of its purpose, read, "Dedicated to the Reuse of our Resources and the Protection of our Environment." ${ }^{32}$ Extracting recyclable materials was also an economic necessity. When lighter packaging and an eco-

31. "Summary: Ames Solid Waste Resource and Recovery Plant April 15, 1976," p. 3, scrapbook 1, Arnold O. Chantland Resource Recovery Plant, Ames.

32. Al Joensen interview. 
nomic recession curbed consumerism and waste, the city's expectations of waste generation fell short in 1977, decreasing to just 48,500 tons. The result was higher costs. Diminished or unreliable income on the material recovery side was another reason the EPA began to favor the shift to the European mass burn technologies. By 1981, only 2 percent of the country's MSW was being processed in resource recovery plants. ${ }^{33}$

RESPONDING TO OBJECTIONS to the high cost of the plant, Ames Public Works Director Arnold Chantland, for whom the plant would later be named, stated, "We need to put some price on the value of land. This system doesn't use up land as in landfills." ${ }^{34}$ Once the energy crisis had passed, most other cities with resource recovery saw no other environmental good to justify their plants. Resource recovery did decrease the need for landfill space and risks of groundwater pollution, but environmentalists increasingly worried more about dangers from air pollution than land-related issues. While scarcity fears earlier in the decade had caused public discussion about farmland preservation, the only federal response was to promote more production through increased land use. During his visit to the Iowa State Fair in 1976, presidential candidate Jimmy Carter called farmers the "first and foremost environmentalists" and stated that "one of the greatest tragedies of the last eight years is the way the administration has cut back on farm conservation efforts. As a companion to building production and stable prices, we must also have conservation programs, to build back the land." ${ }^{35}$

Some areas of Iowa, including Story County, were working on such programs. The county instituted farmland conservation measures during the decade to save what was "widely regarded as some of the most fertile corn land in the nation." ${ }^{36}$ In 1977 the county implemented a zoning plan based on a "corn suitability

33. Oscar Albrecht, "What Happened to the Gold in Garbage?" American City and County, August 1981, 48, 47; Iowa State Daily, 6/25/1981.

34. Iowa State Daily, 6/25/1981.

35. Joel Tarr, The Search for the Ultimate Sink: Urban Pollution in Historical Perspective (Akron, OH, 1996), 50; Jimmy Carter, Remarks at Iowa State Fairgrounds, 8/25/1976, 3, box 404, Jimmy Carter Papers, Jimmy Carter Presidential Library.

36. Des Moines Register, 7/15/1979. 
rating." Planners wanted to stop urban sprawl from eating up cropland, so they rated parcels of land on a scale of 1 to 100 based on their conduciveness to growing corn. The county found that it could meet expected growth through the year 2000 by only allowing the development of land that scored 62 or less on the scale, even though 93 percent of the county's land scored higher than $62 .^{37}$

Not everyone bought into the farmland conservation arguments, including Earl King, the president of a rural power co-op called Allied Power, which in 1979 was trying to find a town in central Iowa willing to host its power plant. King said there was a "bit of phoniness" in the farmland preservation efforts. He pointed to ISU's new football stadium, where, he said, "they play six home-games a year and they don't even use it for practice. They park thousands of cars around there for 20 hours a year to watch a couple of teams play football." ${ }^{38}$

Many people, in fact, shared King's skepticism. Many studies about the nation's rapidly diminishing supplies of farmland had been released in the early 1970s, but, as geographer Michael Bunce points out, "Little evidence was produced to show that the overall level of agricultural output or the integrity of the agricultural economy was being seriously affected." Bunce adds that farm problems in the 1980s were the result of "overproduction and global competition rather than land shortages." ${ }^{39}$

As with other environmental fears - overpopulation for instance - the fact that the dire predictions did not come to fruition within a certain period of time did not mean people stopped being concerned. With these kinds of issues, if conditions did not worsen by a certain point, critics could always argue that society had been spared this time but trouble was still on the horizon if ways were not changed. Another possibility was to find new justifications for the same cause. That is what happened as Ames began to use farmland preservation as an argument for the resource recovery plant.

37. Ibid.

38. Ibid.

39. Michael Bunce, "Thirty Years of Farmland Preservation in North America: Discourses and Ideologies of a Movement," Journal of Rural Studies 14 (1998), 234. 
Bunce argues that the three main non-production justifications to preserve farmland were ecology, "local amenity protection," and agrarianism. In addition to saying that its land was needed for corn production, the city of Ames relied on all three of the other justifications.

The ecological position found its roots largely in the "land ethic" first espoused by conservationist Aldo Leopold, who advised people to "quit thinking about decent land-use as solely an economic problem. Examine each question in terms of what is ethically and esthetically right, as well as what is economically expedient. A thing is right when it tends to preserve the integrity, stability, and beauty of the biotic community. It is wrong when it tends otherwise." Many environmentalists had problems with modern agricultural practices, but turning farmland into a landfill for garbage would have been even worse for a "biotic community." As Leopold said, "The less violent the man-made changes, the greater the probability of successful readjustment in the pyramid." (This was a kind of food-chain pyramid with soil on the bottom; on each layer above that rested species that relied on the layer below it for food. $)^{40}$

If local resources are considered a kind of amenity, then Ames's second non-production justification for farmland preservation becomes clear. After a 1974 National Energy Task Force meeting in Washington, D.C., Juanita Vetter, chair of the Iowa League of Women Voters' Board of Environmental Quality, reported, "Iowa and Missouri were reproached for our reluctance to mine coal, in spite of its high sulfur content and its small pocket type deposits. We explained our concern for the good agricultural earth so vital to the food supply. The plainsmountains representative chorused 'we're being raped so the rest of you can have energy. We're going to look like the moon surface with nothing usable left!' "'41 Iowa did not have oil or good coal. The best thing that Iowa could offer a country wor-

40. Ibid., 237-43; Aldo Leopold, A Sand County Almanac (New York, 1970), 262, 257, 252.

41. Juanita Vetter, chair, Board of Environmental Quality, League of Women Voters, to Iowa branches of the League, 12/12/1974, on Energy Task Force Conference (November 1974, Washington, DC), League of Women Voters Records, Special Collections, ISU Library. 
ried about the future of its resources was farmland. Saving the land gave the state the ability to maximize its contribution to the nation.

In the late 1970s, farmers, trying to emphasize the importance of the nation's, and their own, global contributions, adopted the slogan "a bushel of wheat for a barrel of oil." ${ }^{42}$ Agriculture did account for one-fifth of U.S. exports and offset 62 percent of the trade deficit caused by oil imports, but it could not compete toe to toe with oil. ${ }^{43}$ Plenty of other countries could supply oil exporting nations with food, but not many other countries could supply oil to the United States. In addition, the United States was willing to pay almost anything for oil, as Assistant Secretary of Agriculture Dale Hathaway noted in 1979, but "no one is willing to pay $\$ 20$ for a bushel of corn. ${ }^{\prime 44}$ Agriculture's dependence on oil, which had proliferated by the end of the decade, further weakened the argument that food should have the same standing as energy. By 1980, it took 1.13 barrels of oil to grow a ton of grain. ${ }^{45}$ Some economists and businesses argued that choosing between farm and energy interests should be based solely on which was more profitable. In a five-part series called "Vanishing Acres," written for the Des Moines Register in July 1979, reporter George Anthan quoted a USDA economist who opposed that idea: "According to that kind of reasoning," Anthan said, "we should be taking land out of food production so we can save oil and natural gas. Then we could all sit down and eat oil and natural gas." ${ }^{46}$

That kind of thinking is a mix between the amenity idea and agrarianism. In some cases, converting farmland to other uses might have been a better economic choice. Some farmers, for example, might have been choosing to sell their land to developers. But in agricultural states such as Iowa, the idea that farmland was inherently valuable was a natural one, whether or not economic analyses or actual behavior supported that thinking.

42. Des Moines Register, 7/1/1979.

43. Lehman, Public Values, 60, 150.

44. Ames Daily Tribune, 7/13/1979.

45. Lehman, Public Values, 62.

46. Des Moines Register, 7/12/1979. 
It was an acceptable idea to many other Americans as well. Even though no food production shortage was in sight, a Louis Harris public opinion poll in 1980 showed that over half of all Americans surveyed considered the loss of good farmland to be a "serious problem." City officials would use the inherently valuable status of farmland as a justification for its resource recovery plant over the next three decades.

DURING THE 1980s the plant worked out many of the mechanical difficulties most other resource recovery plants across the country never survived to solve. The Ames plant also benefited from its proximity to ISU with its strong engineering focus. Arnold Chantland started out as a city engineer and became the director of engineering services by the late 1960s, working for the city for 30 years. Well into his retirement he stated, "Engineers believe in taking science and doing something useful with it. Hopefully, the public will accept it and think it's useful." ${ }^{48}$ His pragmatic attitude was typical of engineers, who seek to apply knowledge to problems. The town's mind-set, combined with an unusually high employee retention rate, allowed the Ames plant to build up a body of workers with the knowledge to anticipate trouble and, through much trial and error, to largely eliminate the flaws in the plant's operating system.

The last major mechanical difficulty of the decade occurred in 1987, when a propane tank exploded in the shredder. As plant superintendent John Pohlman recalled, the blast "took the wall off of the South side of the building, and almost blew it out onto Lincoln Way." After that, the plant announced that it would take propane tanks for free, so that people would bring them in rather than attempt to hide them in their trash. ${ }^{49}$

47. Mark Friedberger, "The Rural-Urban Fringe in the Late Twentieth Century," Agricultural History 74 (2000), 507, 508; Frank Schnidman, Agricultural Land Preservation: Serious Land Policy Concern or Latest 'Public Interest' Ploy, Lincoln Institute Monograph \#81-1 (Cambridge, MA, 1981), 1.

48. "How Ames Garbage Helps Heat and Light Your Home," Ames Tribune (online feature), 9/30/2010, http:/ /greentogether.amestrib.com/2010/09/30/ how-ames-garbage-helps-heat-and-light-your-home/.

49. John Pohlman interview; Rob Weidner, lead operator of the Ames resource recovery plant, interview with author, 5/8/2009. 
The Ames plant operated in the red for over 20 years, sometimes costing four times the expected amount. Over that time, however, employees worked out the kinks in the plant. As a city spokesperson told the Tribune in 1995, during those years of deficit, the plant "saved nearly 800,000 tons of garbage from being deposited on more than 80 acres of farmland - enough rubbish to fill Hilton Coliseum 400 times." ${ }^{50}$

While the Ames resource recovery plant chugged along, plans for the European-style waste-to-energy (WTE) plants looked promising for the rest of the country in the first half of the 1980s. That enthusiasm would not last more than a decade, though, and the number of plants peaked at 146 in 1996. Plans for 248 plants had been scrapped from 1982 to 1990, and by the end of the twentieth century there were only 109 plants left. WTE proponents had been optimistic about the 1978 Public Utilities Regulatory Policies Act (PURPA), which guaranteed that alternative energy producers would get paid the same amount for their fuel as suppliers of traditional fossil fuels did. When fears of the energy crisis subsided in the 1980s, fossil fuel prices plummeted, and so did the revenue that WTE suppliers received. ${ }^{51}$ As the Ames plant was municipally owned, its existence did not depend on such profits. When the RDF was worth less, the city could just raise the fees it charged Story County citizens to use the plant.

The second major cause of the WTE letdown in the 1980s was the 1986 Tax Reform Act. Under that law, cities had to pay taxes on bonds for projects that were not entirely publicly funded. That was a devastating blow to the WTE industry; the National Solid Waste Management Association said that taxing the bonds

50. Joan Bundy, “Talkin' Trash: Ames Sets the Pace," Update '95, a supplement to the Ames Daily Tribune, 2/10/1995.

51. H. Lanier Hickman Jr., "A Brief History of Solid Waste Management in the US During the Past 50 Years," Waste Management, Nov.-Dec. 2001, available at www.mswmanagement.com/november-december-2001/solid-wastemanagement-2.aspx (accessed 3/29/2011); Randall Curlee, Waste-to-Energy in the United States: A Social and Economic Assessment (Westport, CT, 1994), 4; Louis Bloomberg and Robert Gottlieb, War on Waste: Can America Win its Battle with Garbage? (Washington, DC, 1989), 141; "Refinements Bolster Trash Plants; But Tax Laws Threaten Multibillion-Dollar Market," Engineering News-Record, 2/23/1984 (accessed on Lexis-Nexis). 
was "really mandating a return to landfilling through tax policy." ${ }^{52}$ Again, because Ames was entirely municipally owned, it was not affected. But even the Ames plant could not escape the third major blow to the push for WTE: a growing environmental sensitivity, especially the increasingly prevalent belief that some high technology threatened environmental health.

IN 1992, four years after the EPA had set a 25 percent recycling goal for the nation's waste, Ames was considering whether or not to continue operating the resource recovery plant, which at the time was diverting 60 percent of Story County's waste and 82 percent of Ames's from a landfill. ${ }^{53}$ The plant's supporters related their opinions about recycling to the most controversial issue of that election year. In an Ames Daily Tribune story, Plant Superintendent Kenny Moravetz said that Ames was "prochoice" when it came to garbage. It was up to Ames residents whether they wanted to sort materials for recycling or just chuck it all. "In most communities," Moravetz said, "you don't have that choice. ... We want residents to not feel guilty when they throw something away." At least a few Ames environmentalists objected to the amount of materials recycled and to Moravetz's "pro-choice" statement. Ames resident Nancy Treu wrote a guest opinion for the Tribune calling the idea "absurd." "It has been and is our selfish and wasteful overconsumption of resources that has gotten us into this problem in the first place," she wrote. "We SHOULD feel some guilt anytime we use up a resource, especially a non-renewable one."

Specific worries about health aspects of the plant also began to arise. "I shudder every time I put a number six or seven plastic container in my trash," resident Peggy Murdock wrote. "I know we don't recycle this grade of plastic because it is too hazardous for the people working in the plants that do that. Can it be any healthier for us to burn it six blocks from my home?" Murdock reversed her position after Merlin Hove, the

52. "Refinements Bolster Trash Plants," 22.

53. Arnold O. Chantland Resource Recovery System 1996 (Ames, 1997), fig. 3; Ames Daily Tribune, 7/30/1992.

54. Ames Daily Tribune, 9/26/1992, 10/1/1992. 
municipal electric system director, contacted her, but her letter showed that fears about air pollution were gaining ground on the farmland conservation issue, even in Ames. ${ }^{55}$

In addition, the plant had yet to show any promise of ever turning a profit. At a community forum to discuss the MSW disposal plans, some residents called the city "ignorant" for using the "incinerator." Paul Wiegand, director of public works in the early 1990s, called the plant a "17-year experiment" and said that when Ames developed a new solid waste plan, recycling would probably be "the number one thing." ${ }^{156}$

The day after Wiegand's statement appeared in the paper, R. W. Beck and Associates, the consultants the city hired to help create its next 20-year solid waste plan, appeared at the city council meeting to recommend that the city keep the plant but adopt a more integrated waste management system that included some type of recycling. When the city council finally held a community forum to decide the plan, the debate focused exclusively on the resource recovery plant rather than recycling. Ultimately, recycling legislation would not happen in Ames. WTE plants operating before 1989 did not have to adhere to the EPA's 25 percent recycling rule, and the city council decided against the shift on the basis of market demand. The council decided that paper and plastics, which made up 27 percent of the waste stream, were more valuable as fuel for the power plant than as recyclables. In addition, there was no need to regulate metals, because the current system already separated and recycled them. "Council members agreed that there was no point in subsidizing a recycling program when the city pays for the resource recovery plant. ${ }^{157}$

THE DEBATE over recycling versus burning did not occur in a vacuum. Pollution concerns about resource recovery plants had existed since the early 1970s. The early fears usually dealt with sulfur dioxide, particulate matter, or bacteria. Testing on European-style mass burn incinerator emissions at the end of the

55. Ames Daily Tribune, 7/9/1992, 7/31/1992.

56. Ames Daily Tribune, 10/12/1992.

57. Minutes, Ames City Council, 10/13/1992; Ames Daily Tribune, 3/25/1993. 
decade, however, had revealed hazardous forms of dioxins, which were often created by plastics and chlorine. The plastics industry had boomed after World War II; by 1985, the United States was consuming 39 billion pounds of plastic per year. Unlike waste that was burned earlier in the century and often deemed a "nuisance," plastic garbage when burned produced toxic chemicals, including dioxins. ${ }^{58}$ Although the evidence was "inconclusive," problems believed to be associated with dioxins included "increases in cancer, birth defects, psychological damage, liver damage, cardiovascular deterioration, and degeneration of the endocrine system ... disturbances in the responses of the peripheral nervous system ... severe weight loss and chloracne, a disfiguring and persistent form of acne growth." ${ }^{59}$

The threat of dioxins was debated, as was the threat of the other air pollutants — including lead, mercury, beryllium, nitrogen oxides, polycyclic organic compounds, carbon monoxide, and hydrogen chloride - which many feared resource recovery plants were releasing. Many in the waste industry did not agree that the level of concentrations released carried such risks, but when a chemical plant in Italy had an explosion that released a "few pounds" of dioxin into the ambient air, leading to an area evacuation, to regular citizens "the extraordinary toxicity of dioxin was widely appreciated, if still poorly understood." ${ }^{60}$

When area residents complained about the bad smells from the resource recovery plant in Hempstead, Long Island, the recent concern about dioxin in European plants caused officials to test emissions. The Hempstead tests revealed "significant amounts" of dioxin in the plant's emissions. According to biologist and environmental activist Barry Commoner, "An intense controversy erupted, first among technicians about the

58. Barry Commoner, Making Peace with the Planet (New York, 1990), 110; Carl A. Zimring, Cash for Your Trash: Scrap Recycling in America (New Brunswick, NJ, 2006), 145; Martin Melosi, Sanitary City: Urban Infrastructure in America from Colonial Times to the Present (Baltimore, 2000), 398-99.

59. Bloomberg and Gottlieb, War on Waste, 98.

60. Ibid., 100; Walter M. Shaub, "Disposing of Waste-to-Energy Facility Ash," in Waste-to-Energy as a Part of Municipal Solid Waste Management, vol. 2, Selected Papers from the Proceedings of SWANA/GRCDA Meetings 1987-1990 (SWANA Publication no. GR-WTE 0401, February 1991), 98, 99; Commoner, Making Peace, 110. 
validity of the results, and later in the community about their significance. ${ }^{\prime 61}$

The controversy over the Hempstead plant gave citizens pause over existent plans for eight new WTE plants. The first was going to be built in the Brooklyn Naval Yard and was supposed to process 3,500 tons of waste per day. Once worries over dioxins broke out, the plant became set on a long course of derailment thanks in large part to the efforts of Commoner. In a scene that would seem familiar 20 years later in Ames, a public relations battle over the Brooklyn plant ensued, with residents wanting to know how dangerous dioxins were and how much would be emitted. The Department of Sanitation (DOS) argued first that there was no risk of dioxins and later that the plant would burn the trash at such a high temperature that it would eliminate any dioxins in the garbage. ${ }^{62}$

Commoner, who began his career as an anti-nuclear scientist in St. Louis, now led the Center for the Biology of Natural Systems (CBNS) at Queens College. He and his crew became involved in New York as scientific experts educating the community about complex scientific issues. CBNS faculty attended public meetings about the WTE plants and provided test results from European plants that countered the DOS arguments. "It became clear," Commoner later wrote, "that the public acceptance of the proposed incinerator would stand or fall on the expected effect of the dioxin emissions on the people exposed to them." As he pointed out, these types of evaluations are particularly difficult because they involve so many different kinds of science: chemistry, physics, physiology, biochemistry, and biology. The engineering firm that the DOS hired to measure the danger of dioxin levels found the risk to be an extra 0.13 deaths per million people. The EPA's acceptable risk level was one extra death per million people. CBNS immediately attacked the study for

61. Commoner, Making Peace, 110. The city of Hempstead had contracted the plant in late 1974, and it opened in 1979 at a cost of $\$ 140$ million. It could process 320,000 tons of waste per year and made enough energy to power itself and 20,000 nearby homes. The contract for the plant ran 17 years, but because of the dioxin concerns it only operated for one. New York Times, 3/30/1987; available at www.nytimes.com/1987/03/30/nyregion/idle-trash-plant-blownup-to-clear-site-for-incinerator.html?pagewanted $=1$ (accessed 3/20/2010).

62. Commoner, Making Peace, 111. 
assuming that the dioxins would be ingested by breathing, leading to a deceptively low risk level. The center conducted its own study and found the risk to be an extra 29 deaths per million, while an outside group estimated the risk at 5.9 per million. ${ }^{63}$

CNBS's most important assertion was that incineration created dioxins. Dioxins did exist in products like plastics, as well as paper and PVC pipes, which used chlorine in production. WTE promoters argued and Commoner agreed that burning materials at certain temperatures could help eliminate dioxins. The problem, Commoner argued, was that the process of incineration itself created new dioxins that did not originally exist in the materials. He said that dioxins were an emergent property of the process of incineration. WTE plants, which Commoner referred to exclusively as "incinerators" or worse, were another example, like nuclear power, of new technology creating new problems. Even if plants got better at controlling emissions, the anti-WTE groups argued that the dioxins present in the remaining ash would be extra potent. Because the process "created dioxin," it was inherently unsafe. ${ }^{64}$

While the national debate was brewing, back in Ames plant employees were emphasizing the recycling side of resource recovery. A subtitle on a Daily Tribune story titled “Talkin' Trash: Ames Sets the Pace" read, "Recycling is a household word here." The story stated, "As the recycling rage sweeps the nation, Mid-Iowans can smile to themselves in the knowledge that they were ahead of their time." The reporter brushed over the more controversial energy production side, writing, "Lest environmental purists begin shouting that burning garbage cannot possibly be good for the environment ... consider that the trash

63. Michael Egan, Barry Commoner and the Science of Survival: The Remaking of American Environmentalism (Cambridge, MA, 2007), 47, 48, 178; Commoner, Making Peace with the Planet, 111-13.

64. Commoner, Making Peace with the Planet, 119, 118. Resource recovery and WTE proponents consider the term incinerator a derisive one, as it does not incorporate the positive, or engineering, aptitude that turns something unwanted into something wanted. Environmentalists, in turn, often object to the terms resource recovery and waste-to-energy, seeing them as euphemisms for processes that entail the destruction and loss of resources and overall waste of energy. See Richard Firstman, "High-Stake Risk on Incinerators," in Rush to Burn: Solving America's Garbage Crisis (Washington, DC, 1989), 14. 


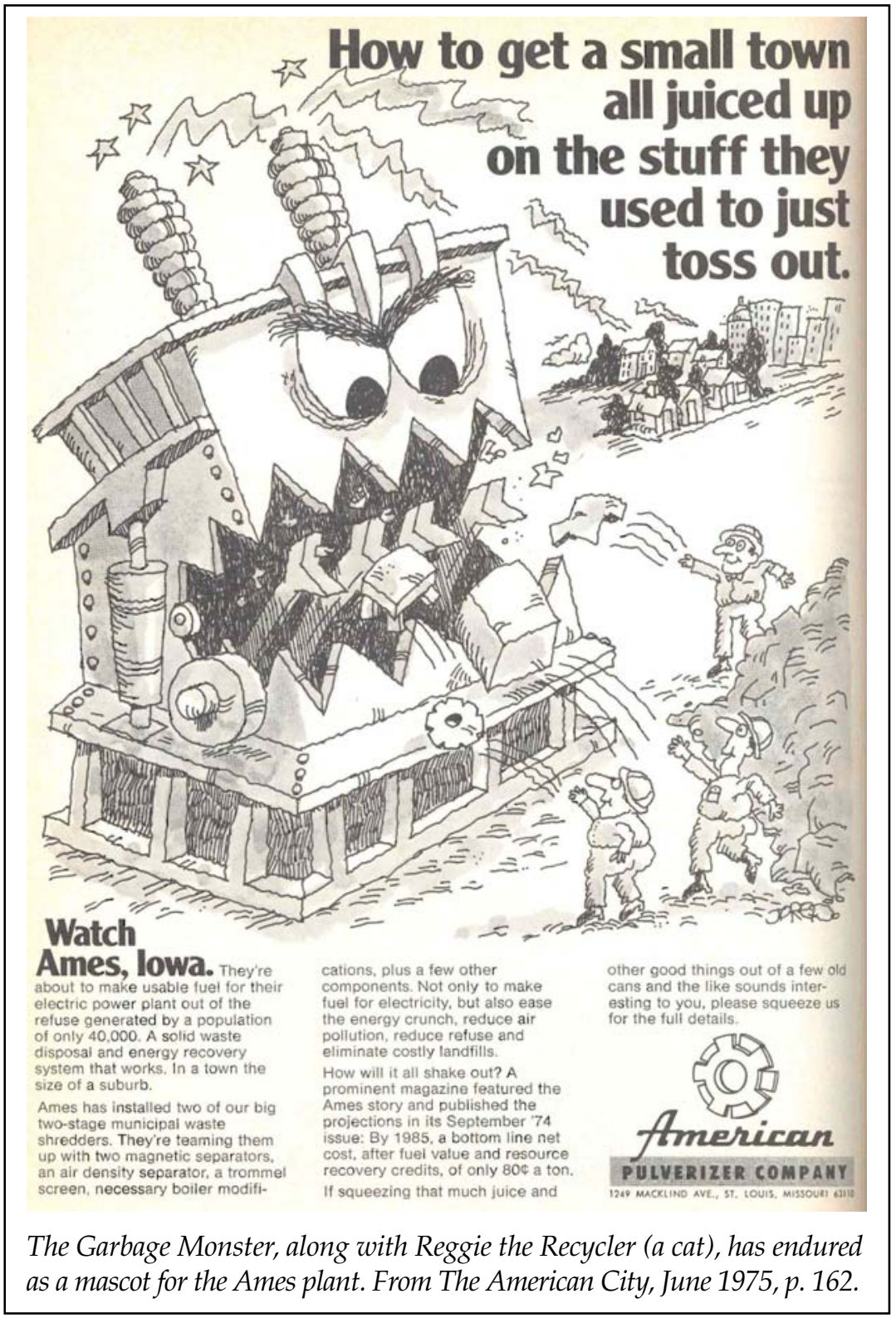

provides enough energy to heat more than 4,600 homes each year." ${ }^{\prime \prime 5}$

65. Ames Daily Tribune, 2/10/1995. 
Most Ames residents seemed to accept that argument and the plant. It is not surprising that burning unmarketable waste would be less controversial in a city with a high proportion of engineers. Environmental engineers generally accept that any type of environmental management will have some cost, an assertion that may be less acceptable to the general public.

Once it had decided to retain the plant, the city's support did not waiver. It invested over \$6.5 million in 1995 and 1996 to replace worn equipment, add new technologies, and build a shredder room outside the main building to avoid future incidents like the propane tank fire. Starting in 1996, the city even began counting the per capita fee it charged for trash service as revenue, allowing the plant to operate in the black for the first time in $1998 .{ }^{66}$ Soon, however, Ames would be directly confronted with the dioxin controversy and its leading protagonist.

In 2001 Barry Commoner and the North American Commission for Environmental Cooperation (NACEC) came out with a study on dioxins in North America. Commoner and the NACEC had been studying causes of cancer among the Inuit Indians who live in Canada's Nunavut territory in the Arctic Circle. Although they are far removed from most industry, the Nunavut Inuit have an average of five to ten times the amount of dioxins in their bodies as other citizens of Canada and the United States. Using a computer-generated model, the NACEC determined that there were about 44,000 sources of dioxin emissions in Mexico, the United States, and Canada, and that due to weather patterns the Arnold O. Chantland Resource Recovery Plant in Ames was the very worst polluter, causing the most dioxins to move north and get trapped in the Arctic Circle. Dioxins do not usually reach the Arctic by air but instead get into water systems, where fish eat contaminated algae. The fish are ultimately consumed by animals with a high body fat content, like the seals that the Inuit rely on for subsistence, in which dioxins can accumulate. ${ }^{67}$

66. Council Action Form, "Subject: Resource Recovery System Analysis and Bid Recommendation," Item \# $17 \mathrm{a}+\mathrm{b}, 11 / 1 / 1994,1$, 2, 4, Ames City Hall; Arnold O. Chantland Resource Recovery System 2000 (Ames, 2001), fig. 3.

67. Ames Daily Tribune, 11/15/2000; Bruce E. Johansen, “The Inuit's Struggle with Dioxins and Other Organic Pollutants," American Indian Quarterly 26 (2002), 480. 
ISU professor Robert C. Brown became the local authority to answer Commoner and his study. Brown had taught mechanical, chemical, and biological engineering at ISU since 1983 . He was a popular instructor who had gained notoriety because of his study of biofuels and was appointed director of the school's Center for Sustainable Environmental Technologies in $1996 .{ }^{68}$ The last time that the Ames plant's stack emissions had been tested was in 1981. Although the test had come back negative for emissions, Brown said that result was based on old technology and that any new test was certain to come back positive. At the time of Commoner's criticism, the EPA did not have any standards for an RDF plant like the Ames one, so any determination about how many dioxins would be too much would have to be decided by a lay city council. Brown said that was a game that the council did not want to get into because it would be highly unlikely that the city would be able to satisfy the critics no matter how much money they spent. The city was going to ask the Kansas City firm Midwest Research Institute to test their equipment, a process expected to cost about $\$ 80,000$. Brown, however, offered to do a study for just $\$ 5,000$. The local scientist said the problem with paying for a more extensive test for the plant's furnace and cooler was that even if the results came back satisfactory, Commoner could say that the dioxins must be coming from somewhere else in the facility. ${ }^{69}$

This kind of debate among scientists is common for issues with subjective values but frustrating for the lay public. Political scientist Sylvia Noble Tesh has studied the issue and found that scientific proof about dioxins is often inconclusive, but emotions have often been powerful enough to change policies. She writes that "extrapolating [risks] from high to low doses ... depends more on political judgment than on scientific data." In the past, testing dioxins on animals (to the degree that was effective, which Tesh said it was not) did not provide any better scientific proof of the dangers of dioxins. As she states, "All the data on humans suggest that people can tolerate considerably higher

68. See biographical statements on the ISU website at www3.me.iastate.edu/ rcbrown/and www.iprt.iastate.edu/centers/bio_brown.html (accessed 3/18/ 2011).

69. Ames Daily Tribune, 4/25/2001, 5/8/2001. 
doses [than lab rats] before being harmed..$^{\prime 70}$ On the other hand, chemist Paul Connett, who worked with Commoner to stop the proliferation of incinerators in the 1980s, asserted that the scientists cited by industry were "working for the industry," while "most other scientists don't know anything about it because they don't have any incentive to study the issue. . . . So our biggest problem is not being attacked by fellow scientists, but rather not having fellow scientists with enough time, energy, commitment or motivation to find out who the hell is right.."71 No industry or profit motive was involved in the Ames resource recovery plant, but the relationship between Brown, the local researcher, and the city was too cozy for Commoner.

Commoner and his crew said that the dioxins were a local danger as well as a problem for those in the nether regions of Canada. The danger, he said, was that the dioxins, which can cause cancer, got into food supplies and would build up in consumers of the food. Any livestock being raised anywhere close to Ames - specifically, Wisconsin dairy cows - would carry on contaminants to consumers. Mark Cohen, the scientist who developed the computer model for the NACEC, said that within two weeks dioxins could have gone numerous different directions, "leaving North America 'awash'" in them. ${ }^{72}$ Commoner's two solutions were to speed up the cooling-off phase, so there would be less time for the dioxins to form, or to ban "incinerators." The plant's long-standing argument had been that dioxins could not form in the 2,800-degree temperatures at which it burned its garbage. ${ }^{73}$

Before he began his study, Brown accepted Commoner's counter to the plant's argument: that dioxins could form in higher temperatures or at least in the cooling-off phases of recovery. He did not accept much else. In his report, Brown called Commoner's conclusions "grossly inaccurate." Commoner had

70. Sylvia Noble Tesh, Uncertain Hazards: Environmental Activists and Scientific Proof (Ithaca, NY, 2000), 29, 28.

71. Edward Walsh, Rex Warland, and Clayton Smith, Don't Burn it Here: Grassroots Challenges to Trash Incinerators (University Park, PA, 1997), 23.

72. Janet Raloff, "Even Nunavut Gets Plenty of Dioxin," Science News 158 (10/7/2000), 230.

73. Ames Daily Tribune, 11/15/2000. 
claimed that the Ames plant was producing 58 grams of dioxins per year; Brown said that number was 400 times too high. Commoner's lumping of the power plant with "incinerators" particularly irked Brown, as the facility was a pulverized coal boiler. Only 20-30 percent of the burned material was garbage, and most metals were taken out before burning. In addition, plant proponents believed that cofiring with coal helped to remove toxins such as sulfur dioxide. Brown said that Commoner "found the worst type of combuster and used it [as a model] for Ames. ... It was the absolute worst. . . . It in no way represents the facility in Ames." ${ }^{74}$

The exchange between the two scientists involved not only different ideas about methods but starkly different ideologies. Brown said that Commoner was advocating rather than doing science. Commoner, for his part, did not believe that the two actions were mutually exclusive. Historian Michael Egan has traced the entwined relationship between Commoner's activism and his science. Commoner believed that scientists' social responsibility was more important than the pursuit of science for its own sake. His entire career had been devoted to fighting against what he saw as technological overkill with inadequate knowledge of consequences. ${ }^{75}$ Brown, however, believed that Commoner's activist platform caused him to create bad scientific analysis. He accused Commoner of having an answer he wanted to arrive at before he even began his research. Besides, Commoner had never studied the Ames plant in person but instead tried to figure out how much pollution the plant produced based on the type of equipment he believed the plant to have and the amount of waste the facility's staff had said was being processed. That, Brown said, was "calculating on the basis of assumptions." Brown also pointed out that the only peer review that Commoner had for his findings was a review by his own staff. Commoner responded that his staff gave the paper "far more scrutiny than any peer-reviewed paper would normally get" and called Brown's conclusions "distorted," "puerile," "un-

74. Ames Daily Tribune, 7/14/2001.

75. Egan, Barry Commoner and the Science of Survival, 57.

76. Ames Daily Tribune, 5/14/2001. 
ethical," and "foolishness." He said that Brown "did his job" by saving the city most of the $\$ 80,000$ that an environmental test would have cost. ${ }^{77}$

Despite the rancor, there was no lasting conflict after the debate, and the city accepted Brown's report as the final word on dioxin concerns. ${ }^{78}$ One reporter said that he remembered seeing Barry Commoner on the St. Louis Walk of Fame and suggested that Ames should build its own Walk of Fame and "include Commoner, if only because he's really given [the city] not to mention me - some interesting work to do." ${ }^{179}$ An underground opposition group called the Ames Quality of Life Network was formed, but it apparently made very little effort to affect the council's decision. ${ }^{80}$ A couple of months later a columnist in a Nevada, Iowa, paper was lamenting the lack of a conservation ethic in her community. "I know [the city's] trash goes over to the Resource Recovery Center in Ames to generate energy," she wrote, "but I'm worried about the talk of dioxins at the plant. I recently read that babies get their lifetime supply of dioxins from six months of breast feeding." ${ }^{81}$ The columnist no doubt expressed a sincere concern, but her words hardly sounded like they were coming from a community with highly mobilized protestors.

TEN YEARS after the debate and 40 years after Ray Fisher first suggested it, the Arnold O. Chantland Resource Recovery Plant abides. It withstood the national death of resource recovery and the push to synfuel production and waste-to-energy plants. It survived shifts in federal policies, a propane explosion, two decades of debt, the recycling movement, and vociferous attacks by one of America's most famous environmental activists. In 2004 consultants suggested that the city close down the power

77. Ibid.

78. Council Action Form, "Approval of Expenditure for Combustion Ash Testing," item 9, 6/14/1994, 1, 2, Ames City Hall.

79. Ames Daily Tribune, 5/14/2001.

80. Michael S. Carolan and Michael M. Bell, "No Fence Can Stop It," in Science and Politics in the International Environment, ed. Neil E. Harrison and Gary C. Bryner (Lanham, MD, 2004), 286-87.

81. Nevada Journal, 8/17/2001. 
and resource recovery plants. Renovation costs for the power plant alone were estimated to be as much as $\$ 157$ million. ${ }^{82}$ The plant survived again, however, as city officials decided for the time being to pay for improvements as necessary rather than abandon the facilities. The "small town with a pretty big idea" has used its savvy to advertise the plant to fit the changing times, but it also has become an anomaly by steadfastly clinging to its original environmental values: a pragmatic faith that technology can be used to solve environmental problems and the belief that the preservation of finite resources like land ought to be a priority. In the face of everything, the Ames plant has demonstrated what Donald Kaul said the country needed during the alternative energy experiments of the 1970s: "Courage to carry out the old solutions." ${ }^{\prime 3}$

82. Ames Daily Tribune, 10/9/2004.

83. Des Moines Register, 7/9/1979. 